University of South Carolina

Scholar Commons

Fall 10-1-1987

\title{
Looking Backward Toward the Future: An Assessment of the Public History Movement
}

Michael C. Scardaville

University of South Carolina - Columbia, mscardaville@sc.edu

Follow this and additional works at: https://scholarcommons.sc.edu/hist_facpub

Part of the History Commons

\section{Publication Info}

Published in Public Historian, Volume 9, Issue 4, Fall 1987, pages 34-43.

http://ucpressjournals.com/journal.asp?j=tph

(C) 1987 by University of California Press

This Article is brought to you by the History, Department of at Scholar Commons. It has been accepted for inclusion in Faculty Publications by an authorized administrator of Scholar Commons. For more information, please contact digres@mailbox.sc.edu. 


\title{
Chairman's Annual Address
}

\section{Looking Backward Toward the Future:}

\section{An Assessment of the Public \\ History Movement}

\author{
Michael C. SCARDaville
}

The best prophet of the future is the past.

-Byron (1821)

IT WAS LOVE at first sight. I vividly remember that warm spring day in 1979 when the latest issue of History News arrived at our state historical agency in St. Augustine. There on the cover were photographs of historians who boldly proclaimed themselves to be "public historians." The editor of the magazine, Jerry George, noted that it was rare to devote almost an entire issue to a single topic, but he believed that this newly defined field had the potential for rebuilding bridges within the historical profession and had implications for the practice of state and local history.

The articles consisted of a litany of the contributions that history could make outside the university and offered specific examples of historians who were making these contributions. Not only did this issue affirm the broader applications of my historical training, it also expressed much of my dissatisfaction with the academic side of history, noting how sessions at professional meetings were oblivious to the concerns of public history, how governing boards of the major historical organizations excluded public historians, how the profession narrowly defined the practice of history, and how people like myself were engaged in "alternative" or "nontradi-

An earlier version of this paper was delivered as the chairman's annual address at the National Council on Public History meeting, held jointly with the Society for History in the Federal Government in Washington, D.C. in April 1987. 


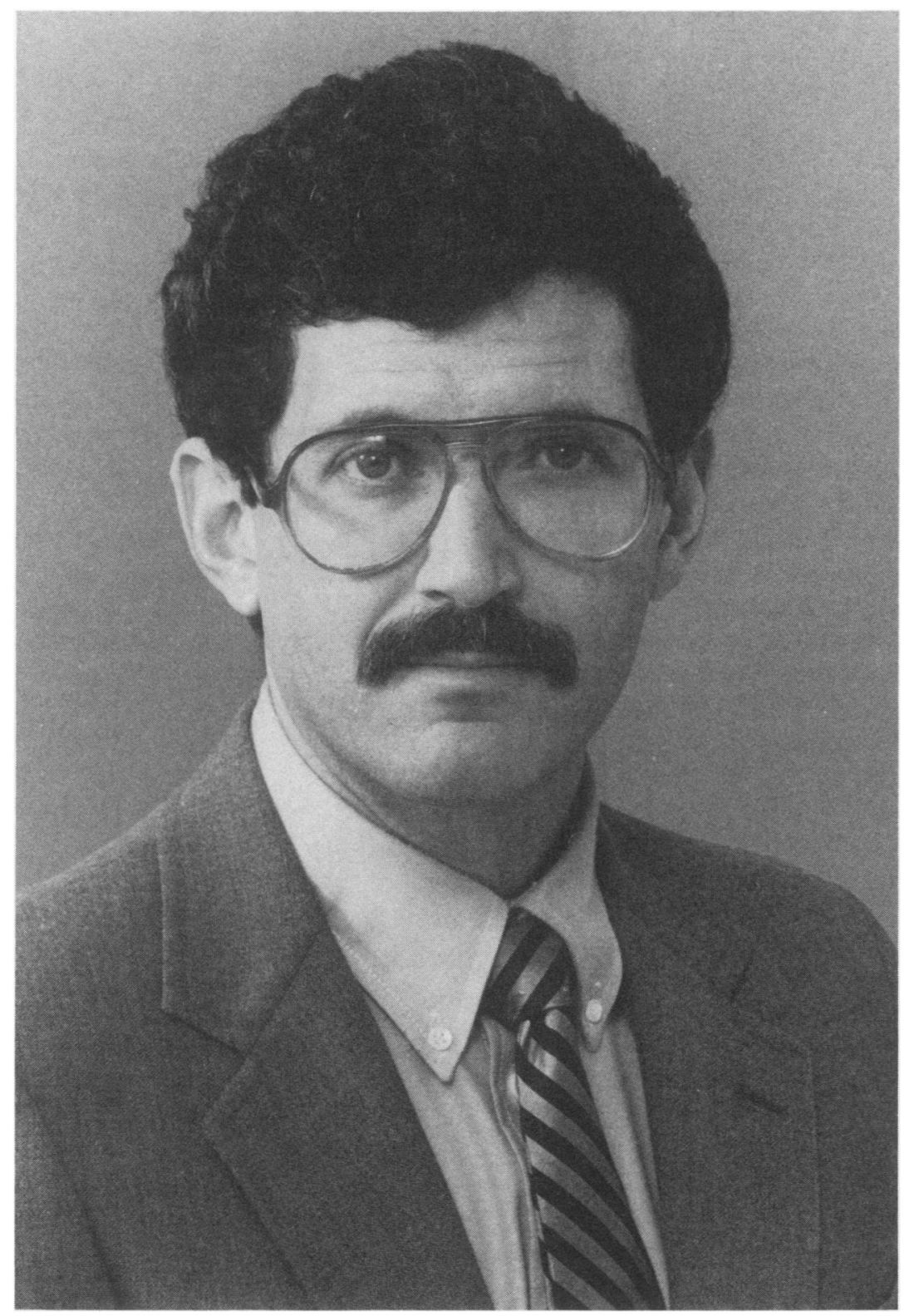

Michael C. Scardaville 
tional" careers. One public historian was quoted as being tired of the patronizing treatment and second-class status afforded by the major historical organizations and weary of public historians being viewed as nothing more than "ants at the professors' picnic."

The concept of public history, first embodied for me in this special issue, began to solve a problem of professional self-identity. I did not want to define myself as a preservationist or a curator. Even though I had been exiled by my graduate committee, I never ceased thinking of myself as a historian, and I wanted to maintain that identity since I strongly believed the discipline had something to offer. I kept asking myself why the state of Florida had committed millions of dollars to create a museum village in the nation's oldest city. Why were we restoring buildings, staffing them with interpreters, and hiring people to stroll through the streets in eighteenth-century period dress? Where was the history in all this? Why should we save? Why interpret? Was it to increase property values in the surrounding downtown or enable the town's merchants to sell more plastic alligators? Living history to me meant a living past, a past that could be used to interpret the experience of the present and give some sense of direction for the future. To me, the past was not dead and irrelevant; the present was not self-explanatory. Public history, as defined in that issue of History News, began to provide some answers to these and other questions which had never been raised during my professional training.

So I quickly embraced this thing called public history, even though I never consciously planned to be this breed of historian. Those smiling faces on the cover of History News offered a lifeline to the historical profession. They made me realize I was not alone in my concerns.

I have seen the public history movement grow since that eventful spring day. The number of academic public history programs has doubled; the National Council on Public History has expanded from a small Board of Directors to a growing membership organization; new public historical organizations, such as the Society for History in the Federal Government, have been established; public historians are now serving on the governing bodies of major historical organizations; and, as a barometer of acceptance, the Employment Information Bulletin published by the American Historical Association now lists jobs under "Public History," not "Nonacademic."

Despite these apparent successes, I have become troubled by some of the developments over the last decade and by some discernible current trends. I admire the accomplishments, but the public history movement, as it matures, should not be immune to a restrospective assessment. I believe the movement has become fraught with its own inconsistencies which limit its full potential. But before we can speculate on the future direction of public history, we should first examine its roots within the historical profession. If we are to properly assess the state of public history today, we need to examine the conditions within the profession that gave rise to the movement. An overview of the history of the profession can 
provide a necessary perspective for better assessing what we have accomplished and what remains to be done, so we know whether we have begun to meet those challenges outlined in History News almost a decade ago.

While many academically based historians continue to regard public history as a new field, a temporary response to the job crisis of the last fifteen years, most of us here know that history has been practiced outside the academy for generations and that public history will remain an important part of the historical profession in the future. Too many historians still view public history as a fad or perhaps as peripheral to the profession because they have so little sense of the profession's development. It never ceases to amaze me that the historical profession is essentially ahistorical. To what extent have most of us or even today's graduate students been exposed to a comprehensive understanding of how the profession, both academic and public, evolved? I contend that few historians know (or at least want to acknowledge) the multi-dimensional origins of the profession, and, as a result, few possess sufficient insight into the evolving definitions concerning the nature and purpose of the discipline. Without this understanding it becomes difficult to assess the current and possible future directions of the public history movement. Therefore, let us pause and briefly review the development of the historical profession and the place of public history within it.

Well before and even after the founding of the American Historical Association in 1884, history generally was practiced in this country by either patrician historians or historical societies. Independent scholars such as Francis Parkman and William Prescott wrote for public consumption and attracted a considerable popular following. Such grassroots interest in history also was reflected in the prodigious growth of state and local historical societies after the Civil War.

The early leaders of the American Historical Association recognized this pattern. Unlike the organizing bodies of other contemporary professional organizations, the charter members of the AHA consisted mainly of nonprofessionals, i.e. patrician historians or such history-minded public officials as William T. Harris, the U.S. Commissioner on Education, and Carroll Wright, the first commissioner of the U.S. Bureau of Labor. Reflecting the feeble state of academically based history, only one in four of the charter members had careers devoted primarily to university teaching.

Due to the efforts of Herbert Baxter Adams, the secretary of the organization, the first two decades of the AHA were generally characterized by cooperation between academic and public historians. Adams wanted the association to be a truly national organization, one that would represent both groups and a variety of institutions. Even though he received rigorous historical training at the University of Heidelberg in Germany, Adams did not stress distinctions between the professionals and the nonprofessionals. With two exceptions, the presidents of the AHA before 1907 were nonacademics, including a U.S. senator, a diplo- 
mat, and an independent historian. Moreover, the organization issued awards to such history-minded public officials as Simeon Baldwin, the chief justice of the Connecticut Supreme Court and one-time president of the American Bar Association.

Adams also courted and assisted the state and local historical societies by initiating bibliographies of their publications and by forming a public archives commission to survey the state of public records. The recommendations resulting from this turn-of-the-century survey were instrumental in establishing state archives in more than half the states by 1910 . These activities are just a few that the AHA sponsored in a genuine effort to represent the interests of all historians.

Another feature of the early years of the profession was a concern for the usefulness of history. The first guide to historical scholarship, published in 1882 by Charles Kendall Adams, stressed that current national problems could be understood and better solved by historically informed public leaders. History graduate programs like the one at Columbia University were established to train both scholars and public officials. And most of the early presidential addresses of the AHA reflect a concern for the practical value of historical study. Few of the organization's presidents valued history for its own sake. Most believed that the past should be studied for the sake of the present and that historians should justify their existence by examining historical problems that would make contemporary problems more intelligible. The dominant justification of the discipline in the early years was clearly its utility and practical application.

Herbert Adams actively pursued several ideas that would facilitate the integration of history in public life. He proposed, for example, that the federal government establish a national academy in Washington which, with history as its core curriculum, would train professional civil servants, just as the military academies train officers. Moreover, he advocated affiliating the AHA with the federal government to ensure that historians and the organization could have an impact on national political life.

Despite such positive efforts in the early years, a wedge began to appear between the nonacademic and the increasing number of academic historians. The latter started criticizing what they considered the provincial and antiquarian nature of nonacademic research in state and local history. The American Historical Review, established in 1895, mirrored this sentiment by publishing articles of increasingly narrow scope aimed at the academic scholars. The growing alienation within the profession also can be seen in the work of the Committee of Seven, an AHAappointed body of academic historians who proposed a standard public school history curriculum which, contrary to the interests of most of the organization's members, did not include state and local history.

These and other activities encouraged disgruntled members in 1907 to form the Mississippi Valley Historical Association for the purpose of securing "cooperation between historical societies and departments of history." 
This precursor to the Organization of American Historians was the first of several major historical organizations, including the Society of American Archivists and the American Association of Museums, that would be established in the first half of the century in part as a reaction to a nonresponsive AHA. These organizations for essentially nonacademic historians and others were clearly designed to meet the needs-through workshops, publications, and technical information-of the public side of history.

Wishing to reintroduce the academic community to the public and capitalize on the immense popular demand for history, AHA leaders such as Allan Nevins of Columbia University and William Langar of Harvard proposed that the organization sponsor the publication of a popular magazine of history. Opponents of the measure insisted that the profession stick to pure scholarship and avoid any hint of commercialism, an attitude that marked their unwillingness to teach and practice history outside the classroom. The defeat of the proposal led the Confederation of State and Local Historical Societies, a subgroup within the AHA founded in 1904 to strengthen ties between public and academic institutions, to withdraw from the association in 1940 to form a new organization, the American Association for State and Local History (AASLH), that would better represent their needs and concerns. Their popular history magazine finally appeared as American Heritage in 1954 and within two years boasted a circulation in excess of 200,000 .

The formation of the AASLH illustrated the growing division between academic and public historians; by the Second World War, that division was complete. The academic and public historical communities would go their separate ways with little formal communication or cooperation between them. With the booming academic job market of the postwar years, there was little incentive for the academic community to be concerned with their public sector counterparts. The postwar generation of professional historians was, most unfortunately, being trained without an understanding of the broader application and purpose of history. The profession had strayed from its roots; it had forgotten its past.

The result of this separate but unequal relationship has not been in the best interests of the profession. One example can be seen in the development of a national preservation agenda in the postwar years, a process which did not include the active participation of professional historians. Preservation policy was formed and implemented in the fifties, sixties, and seventies without much direct involvement of non-public historical organizations. The role of history and that of historians in preservation efforts today still suffer as a result of our earlier professional myopia.

Most of us here have witnessed first-hand the challenge to the caste system that emerged in historical circles by mid-century. And we know that the job crisis in the academic community served as the catalyst in opening the lines of communication. But we also know that the historical field was expanding-witness the growth in preservation and museum 
programs in the decade of the Bicentennial. Only the academic field was in trouble. So public history was created, a field new in name, not in practice, as the vehicle to broaden the vision and scope of academically oriented historians and organizations. But let us not explain the recent public history movement in strictly market terms, for whatever its origins and justifications, its emergence may very well represent a critical point in the history of the profession in that it openly challenges the narrow notions of who we are and what we do.

This review, however, suggests several shortcomings in the way the public history movement has evolved within the historical profession. The development of the profession has solidified barriers not only between academic and public historians, but also among public historians. Historians go by the names of archivists, curators, and preservationists, and the organizations to which they belong perpetuate the differences among them. Unfortunately, the term "public history" has tended to formalize these divisions afflicting the historical profession. It has caused resentment among those historians who have worked for years outside the academy, historians who wondered what was so new about it. This initial hostility or perhaps bewilderment has made it difficult for the public history movement to gain acceptance within other public historical circles. The basic problem with the term is that it tends to refer to one's place of employment, not to a certain historical approach to problems. As such it highlights historians' differences, not their commonalities, whether they work in a history department, consulting firm, business, cultural institution, or government agency. Most historians teach in one form or another; most engage in historical scholarship as well. The difference lies not so much in their place of employment, but rather in the intended use of the historical effort, the targeted audience, and the conditions of the work environment.

These barriers within the profession have become obstacles for historians who would like to move from one area into another as is more commonly done in other disciplines. My colleagues in political science, sociology, business, and the sciences, for instance, find it logistically easier to alternate between the academy and the public and private sectors. Historians have found it more challenging to flow from one sector to another. In short, the on-going healing process within the historical profession has not yet overcome the many divisions that emerged and solidified by midcentury. While today there may be greater recognition of the diversity within the profession, the barriers are still formidable.

Another shortcoming of the last decade has become evident as well. While we in today's public history movement have boasted of breaking new ground, we have followed traditional academic models that in many instances are not applicable in nonacademic settings and do not assist us in improving the practice and understanding of history throughout society. The models or approaches embraced have not necessarily been the most 
appropriate for accomplishing these objectives. In the last decade, public historians have established historical organizations that exhibit all the trappings of academically oriented organizations, replete with professional meetings consisting of formal papers, a journal, and even an annual address by the president or chair. All this, I believe, has been done largely to gain credibility in academic circles. The university training that this generation of public historians has received and the resulting professional values have forced us to seek respectability in traditional historical organizations. The iron hand of von Ranke still looms large. While this approach has been successful to some extent, it has blinded us from seeking ways in which we as public historians could be more effective. As a result, we find ourselves essentially talking to ourselves, preaching to the converted.

With such shortcomings, I am not overly impressed by the quantitative measure of public history's success in the last ten years, i.e. the number of National Register listings, the number of artifacts curated and exhibited, the number of documents deacidified and edited, the number of academic training programs established, or the number of public history sessions on the programs of the American Historical Association and the Organization of American Historians. The real measuring stick of success is the extent to which historical consciousness has become engrained in the American mind-set, the extent to which the average American and policymakers understand the past as a basis for understanding the present. Have we truly been successful at integrating history into the mainstream of American society? What have we done to promote a "history ethic"?

The intent of this assessment has been to define issues and concerns that we should face in the future if public history is to reach its full potential. I would like to suggest four interrelated issues which deserve some attention to redress the shortcomings just discussed.

The first is that we need to rethink how we can fulfill our mission of strengthening the role of history in society. In doing so, it is imperative to search for new or at least complementary models and approaches. We must find new ways to reach an audience that heretofore has been neglected, such as the users of history, the policymakers, the people who unwittingly use history in the public and corporate decisionmaking process, but who have not been exposed to what the application of professional history can accomplish. We cannot arrogantly wait for these people to come to us; we have to go to them. Historians should attend and participate in their conferences and publish in their journals and newsletters. To date, the historical profession has relied on individual historians, in many instances consulting historians, and on several public history programs to promote the use and practicality of history. We have left the marketing of history to a few without offering the collective support of the profession. We have spent much time over the last decade convincing the 
historical profession of the viability of public history; we now must work to convince the nonhistorians.

Also, if we are interested in generating a "history ethic," we should begin to pay attention to improving the way history is being taught in our public schools. Why has the profession ignored this important area? Why have we directed our efforts mainly at adults? Despite misguided interest early in this century, the historical profession, with the exception of those in the museum field and the writers of textbooks, has done little in any systematic way to advance the teaching of history to our school-age children. The profession can join with such groups as the National Trust for Historic Preservation in promoting what is being called "heritage education" in the nation's classrooms as a way to increase historical understanding in everyday life.

A second major issue we should address more directly is the need to dissolve barriers among historians. This can be approached on several levels. One, of course, is to systematically build bridges among the various historical organizations through joint meetings and sessions as well as through cooperative projects and activities. Another is to find ways to encourage and facilitate the use of the Intergovernmental Personnel Act to its fullest extent. The IPA, authorized by Congress in the 1970s, is designed to foster exchange between public sector employees and academicians, although to the best of my knowledge, it has been used sporadically in historical circles. We impoverish ourselves as a profession when we work within a narrowly defined environment, one which does not encourage a cross-fertilization of ideas and approaches.

Another issue is the need to recognize that independent historians have become vital actors in the way public history is being practiced today. Many historians reared in the so-called traditional ways feel uncomfortable about interacting with those historians who do not possess any institutional affiliation or who do history for profit. Today there are hundreds of such historians, and this expanding group contains some of the most talented people in the profession. Yet we have not figured out how most effectively to relate to this group through a professional organization, nor do we even know how the profession can meet their needs. Other professionals, such as the architects, have come to terms with members who do not possess any sort of affiliation. Others, like the archaeologists, are still struggling to determine how to contend with the independent professionals. We historians should be better prepared to define the role of the independent historian if we wish to be as broadly based and diverse as possible.

Finally, we need to address the professional development of historians, regardless of their affiliation or place of employment. Most of the principal historical organizations have focused their educational attention on academic training programs. They have demonstrated more concern for the 
future generations of historians than for the ones already in the field. A problem with this approach is that many in public history and historyrelated positions have received little formal training in the discipline, and many professionally trained public historians have found it difficult to identify and participate in any form of professional development. In short, the profession has largely neglected historians who have wanted to enhance their skills and knowledge in various historical areas. We need to create opportunities for professional development, opportunities that can be managed within existing time and institutional constraints. Academic programs, targeting working public historians and/or teachers, can consider sponsoring workshops and seminars as well as summer programs and field schools. Professional organizations can begin to structure their conferences to satisfy more adequately the continuing education needs of their members. In fact, we might want to reconsider the nature and purpose of our annual meetings, perhaps affording less time to paper sessions and more time to workshops and discussion sessions which would focus on emerging issues and topics. The cumulative result of these efforts in professional development might very well improve the practice and understanding of history even within the profession.

What strikes me most about this meeting in Washington is that the two co-sponsoring organizations can most readily address these and other issues. The National Council on Public History has already made progress in some areas, including the "History and Public Policy" project, the preparation of directories of consultants and of professional development opportunities, discussion of the Intergovernmental Personnel Act, and a greater emphasis on continuing education at next year's meeting. But much more needs to be done.

As we enter the second decade of the public history movement, we should ask ourselves if we want to continue along what have become the traditional lines and models, focusing on the trappings of the academic profession, or are we willing to build upon this foundation to reach out in new directions? The answer to this may be found in a comment made by James Harvey Robinson, a proponent of the so-called "New History," about the potential and challenge facing historians in 1912: "The one thing that [history] ought to do, and has not yet effectively done, is to help us understand ourselves . . . and the problems and prospects of mankind. It is this most significant form of history's usefulness that has been most commonly neglected." 1

More than a half-century later, the challenge still awaits us.

1. James Harvey Robinson, The New History (New York: The Free Press, 1912), 17. 